\title{
Diagnostic Value of Leptin in Chronic Obstructive Pulmonary Disease of the lii Degree in Patients with Excessive Body Weight
}

\author{
Nadiia Korzh*, Mykola Ostrovskyy
}

\begin{abstract}
Chronic obstructive pulmonary disease (COPD) still remains a serious problem for the public health care system, since it commonly causes disability and mortality among the working population. Frequent combination of COPD with concomitant diseases is a key factor in predicting COPD consequences. Recently, the number of patients with a combination of COPD and overweight is on the increase, which is considered as a mutual aggravating factor and negatively affects the prognosis of the disease in such patients.

The objective of this study was to investigate the diagnostic value of leptin in progression of COPD (III degree of bronchial obstruction in patients with overweight) course by studying its level in blood serum.

Materials and methods: There were examined 112 patients with chronic obstructive pulmonary disease (COPD GOLD III) in different phases of pathological process. The pulmonary function (PF) test was performed by means of "SPIROKOM" device (Ukraine). The degree of overweight was determined by calculating the body mass index (BMI) using the formula I $=\mathrm{m} / \mathrm{h}^{2}\left(\mathrm{~m}\right.$ - body mass in kilograms, $\mathrm{h}$ - height, in square meters $\left(\mathrm{kg} / \mathrm{m}^{2}\right)$. The level of leptin of systemic inflammatory markers was determined by a solid phase enzyme-linked immunosorbent assay in blood serum: "DRG Leptin Elisa" (Germany).

Results and conclusions: The study revealed that overweight leads to a more severe course of COPD (III degree of bronchial obstruction), and the determination of leptin may serve as a diagnostic criterion in the progression of this pathology.
\end{abstract}

Keywords

chronic obstructive pulmonary disease; overweight; respiratory function; leptin.

Ivano-Frankivsk National Medical University, Ivano-Frankivsk, Ukraine

${ }^{*}$ Corresponding author: nadiyakorzh@gmail.com

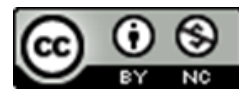

Copyright (C)Nadiia Korzh, Mykola Ostrovskyy, 2019

\section{Problem statement and analysis of the latest research}

Chronic obstructive pulmonary disease (COPD) is a common disease characterized by persistent progressive restriction of airway patency and remains one of the most common human pathologies requiring new global resources for its early diagnosis and prevention of its rapid progression.

This disease is the focus of attention mainly because of its progressive course, loss of productivity, high rates of disability and mortality [8]. Thuswise, in 1990 COPD was ranked the $6^{\text {th }}$ among all the causes of death and in $2001-2.7$ million people died of this disease that accounted for $5 \%$ of all lethal cases all over the world [16, 17, 25]. According to the data of the World Health Organization (WHO), COPD affects 210 million people and its incidence is expected to increase at $30 \%$ in ten years (WHO, 2014). Furthermore, the key factor, which determinates the urgency of COPD issue, is its high treatment costs for both the health care system and 


\section{Diagnostic Value of Leptin in Chronic Obstructive Pulmonary Disease of the lii Degree in \\ Patients with Excessive Body Weight - 2/7}

society as a whole. The statistics of Global Initiative (GOLD, 2019) shows that EU annual direct COPD costs reach 38.6 billion euros. Total COPD costs are three times higher than those for bronchial asthma [7, 25].

Low level of early diagnosis of COPD, as well as lack of awareness among the population and low alertness of medical practitioners towards patients with early symptoms and risk factors for the disease development are the main causes of sharp increase of COPD morbidity rates and mortality due to the disease complications [5, 6, 14]. Recently, special attention is paid to the fact that comorbid pathology can exacerbate the course of COPD and is considered to be an important part of "causative pathogenetic cycle". The likelihood of occurrence of systemic reactions varies at different COPD stages, and the frequency of their comorbid course increases with the disease progression. Frequent combination of COPD with comorbid conditions is a key factor in predicting COPD consequences. Some of these diseases develop irrespective of COPD, while others have causative connection with COPD: these diseases have either common risk factors, or one disease increases the risk of development of other pathology [25].

One of the conditions that can have a negative impact on the course of COPD is the presence of excess body weight, which can lead to the increased morbidity and mortality, lost of productivity and disability, as well as a factor in the rapid progression of a number of chronic diseases, including respiratory tract pathology (L.M.Niu, 2012; N.Hizawa, 2013; K.F. Rabe, 2014). According to the WHO normal body mass index (BMI) is considered to be between $18.5-24.9 \mathrm{~kg} / \mathrm{m}^{2}$, while the BMI of between $25.0-$ $29.9 \mathrm{~kg} / \mathrm{m}^{2}$ is considered as overweight.

The results of experimental and clinical scientific studies intensively performed during the last decade, revealed a new phenomenon: excessive body weight is accompanied by inflammation of adipose tissue, which occurs with its infiltration by immune cells. Moreover, the severity of this inflammation clearly correlates with the degree of obesity $[1,2,11,13]$. Since the inflammatory reaction occurs in tissue that is well-vascularized and inner- vated, the proportion of which can be up to $50 \%$ or more of the total body weight, therefore systemic manifestations should be expected $[3,4,10]$. Nowadays, it has been determined that adipose tissue produces many hormone-like substances, mediators, cytokines and chemokines, which were generally termed as adipokines or adipocytokines. They function both locally and systematically $[9,15]$. Leptin is one of the adipokines synthesized by the adipose tissue; it activates inflammation, promotes angiosteosis, initiates oxidative stress, increases the tone of sympathetic nervous system, changes cytokine regulation, which plays an important role in the pathogenesis of inflammatory damage $[1,12,22]$.

The key elements connecting COPD and overweight involve systemic inflammation and dysfunction of antioxidant mechanisms [10, 18, 19]. Significant vascularization of lungs, the presence of leptin receptors in alveolar and bronchial epithelial cells, smooth muscular cells and bronchial submucosal membrane, as well as increased blood serum leptin levels in patients with COPD exacerbation, allow suggesting pathogenic contribution of leptin to the disease progression $[20,21]$. Leptin also activates the production of mucin by the epithelial cells of the airways, resulting in hypersecretion of mucus, stimulates the synthesis of proinflammatory mediators that contribute to the increase of wall thickness, subepithelial fibrosis, hypertrophy and proliferation of bronchial smooth muscles [12, 21, 24].

At present, the implication of leptin is evidenced both in COPD exacerbation and during its stable period [21, 23, 24, 25, 26]. Many scientific studies have been performed in order to research the role of leptin in the development and course of COPD in Ukraine and other countries. For example, there are well-known publications which indicate that adipokines are associated with systemic inflammation in COPD exacerbation [15, 20, 21, 25]. At the same time, adipose tissue is considered to be an additional source of inflammation $[3,7]$. Thuswise, one of the studies show that the level of leptin in adipose tissue correlated with the level of inflammatory markers in systemic circulation [13, 15, 20]. However, during these studies (Krommidas G., 2010), patients were not classified accord- 


\section{Diagnostic Value of Leptin in Chronic Obstructive Pulmonary Disease of the lii Degree in \\ Patients with Excessive Body Weight - 3/7}

ing to the level of body overweight as compared to the respiratory function, but were evaluated in the general cohort. This issue was also studied in patients with bronchial asthma, which proved the increase of leptin level that is associated with the decrease in pulmonary capacity (PC), forced vital lung capacity (FVLC) and peak expiratory flow rate (PEFR) [1, 10, 23]; however, the role of leptin in the process of generalization of the inflammatory response with FEV1 index below 50\% in COPD patients with excessive body weight still remains uncertain.

The objective of the research work is to investigate the diagnostic value of leptin in progression of COPD GOLD III course in patients with excessive body weight by studying its level in blood serum.

\section{Materials and Methods}

The verification of the diagnosis of COPD and its formulation was carried out in accordance with International Recommendation of the Global Initiative for Chronic Obstructive Lung Disease (GOLD 2019), and the Order of the Ministry of Health of Ukraine \#555 dated June 27, 2013 "On approval and implementation of medical-technological documents on standardization of medical care in chronic obstructive pulmonary disease". Patients being in a stable phase of the process received basic therapy in accordance with the currently valid Order of the Ministry of Health of Ukraine \#555 dated June 27, 2013, which involved the use of long-acting bronchodilators, inhalational and/or systemic glucocorticosteroids, and, if necessary, short-acting bronchodilators [14].

The main treatment group involved 45 patients suffering from COPD GOLD (male patients - 37 (75.6\%), female patients - $11(24.4 \%)$ with obesity); the average age was $(61.9 \pm 3.1)$ years. They were divided into subgroups depending on the phase of the pathology: subgroup I included 18 patients (40\%) with stable phase of pathological process, subgroup II involved 27 patients $(60 \%)$ in the noninfectious exacerbation phase. The experimental group consisted of 67 COPD patients with the III degree of bronchial obstruction (male patients -51
(76.1\%), female patients 17 (25.4\%) with normal body weight; average age - $(62.9 \pm 2.8)$ years. They were also divided into subgroups depending on the phase of their pathology: subgroup I included 25 patients $(37.3 \%)$ with stable phase of pathological process, subgroup II involved 42 patients $(62.7 \%$ ) in the non-infectious exacerbation phase.

The control group involved 23 apparently healthy individuals (AHI) representative by sex and age, without any signs of pulmonary diseases or other pathologies of internal organs, 12 of them were overweight. The study was performed in the phase of remission and at the time of verification of the development of exacerbation phase. All the studied patients gave their consent to participate in clinical trial.

The average duration of the disease in patients with COPD of the III degree of bronchial obstruction was $(26.8 \pm 1.4)$ years in those with overweight, and (31.4 \pm 1.2$)$ years in patients with normal body weight. Among the existing risk factors, which triggered the COPD development in both main treatment group and comparison group, tobacco smoking was prevalent: 29 individuals $(64.4 \%)$ with average smoking history of $(17.8 \pm 2.1)$ pack-years and 48 individuals (71.6\%) with average smoking history of (19.9 \pm 2.2$)$ pack-years, respectively.

Computed spirometry with the help of "SpiroCom medic" (The National Aerospace University "Kharkiv Aviation Institute", Ukraine) was used to study the indices of respiratory function with indicators of main bronchial-obstructive indices (forced vital capacity (FVC) of lungs, forced expiratory volume (FEV1)), according to the criteria GOLD 2014.

The levels of leptin in blood serum was determined using a solid phase enzyme-linked immunosorbent assay with agent "DRG Leptin ELISA" (Germany).

Statistical processing of research materials was carried out using biometric analysing methods implemented in software packages Microsoft Office Excel 2016 (Microsoft Corp., the USA). The assessment of statistical significance of mean values for independent samples was performed according to the Student's and Mann-Whitney tests, while dis- 
Table 1. Table 1. Indices of respiratory function (\%) in COPD patients with the III degree of bronchial obstruction in relation to the body weight, $(\mathrm{M} \pm \mathrm{m})$.

\begin{tabular}{l|cc}
\hline Indices in subgroups of examined patients & \multicolumn{2}{|c}{ Rated values } \\
\cline { 2 - 3 } & Phase of remission & Exacerbation phase \\
\hline FEV1 (\%) & $40.2 \pm 3.1$ & $33.3 \pm 3.0$ \\
Main treatment group, $(\mathrm{n}=45)$ & $45.5 \pm 3.4$ & $38.4 \pm 3.2$ \\
Comparison group, $(\mathrm{n}=67)$ & & \\
\hline FVC (\%) & $67.3 \pm 3.0$ & $62.6 \pm 3.6$ \\
Main treatment group, $(\mathrm{n}=45)$ & $72.6 \pm 3.7$ & $69.1 \pm 3.1$ \\
Comparison group, $(\mathrm{n}=67)$ & & \\
\hline FEV1/ FVC & $55.2 \pm 3.2$ & $53.4 \pm 3.1$ \\
Main treatment group, $(\mathrm{n}=45)$ & $57.5 \pm 3.8$ & $57.1 \pm 3.0$ \\
Comparison group, $(\mathrm{n}=67)$ & & \\
\hline
\end{tabular}

persion was evaluated with the help of Fisher's test. The difference between the comparative values was considered to be significant at $\mathrm{p}<0.05$, while the tendency of changes was indicated in the range of $0.05<\mathrm{p}<0.10$, with the index rate calculated to the decimal place.

\section{Results and Discussion}

The values of main spirometric indices of respiratory function in the main treatment group and the comparison group were identical (Table1).

Laboratory findings show that serum leptin level in patients with COPD GOLD III with normal body weight in the remission phase was 1.6-fold $(p>0.05)$ higher as compared to the control group, and increased significantly with the destabilization of the process. Thus, in the exacerbation phase, the blood serum leptin level was 1.4-fold ( $p>0.05)$ higher than in the remission phase and 2.2-fold $(\mathrm{p}<0.05)$ higher than the control group data (Table 2).

The highest blood serum leptin level was observed in patients suffering from COPD GOLD III with overweight. This index in the remission phase was 2.4-fold higher $(\mathrm{p}<0.05)$ than the control group indices. In the phase of pathology exacerbation the blood serum leptin level in patients with COPD GOLD III with excessive body weight was 1.8 -fold $(\mathrm{p}<0.05)$ higher than the indices in the remission phase, and 4.4-fold $(\mathrm{p}<0.05)$ higher than the indices observed in control group.
The study showed correlation between the level of leptin and excessive body weight that is evidenced by the increase of indices obtained in main group of patients. Namely, serum levels of leptin in patients with COPD GOLD III with excessive body weight in the remission phase were 2.6-fold $(\mathrm{p}<0.05)$, and in the exacerbation phase -3.3 -fold $(\mathrm{p}<0.05)$ higher than the corresponding indices in patients with COPD GOLD III with normal body weight.

We have studied ESR in order to bring accessibility to general practitioners - in family medicine and reduce financial burden in parallel with leptin level.

The study also showed deviations in laboratory indices of patients with COPD GOLD III. Thus, the ESR index in such patients has increased up to $(12.9 \pm 2.1) \mathrm{mm} / \mathrm{h}$, and in patients with overweight this index was $(17.8 \pm 2.3) \mathrm{mm} / \mathrm{h}$, but more pronounced changes were observed in patients with destabilization of the process. Accordingly, the index of ESR in patients with normal body weight increased up to $(17.3 \pm 2.5) \mathrm{mm} / \mathrm{h}$, and in patients with excessive body weight it was $(22.5 \pm 2.0) \mathrm{mm} / \mathrm{h}$. Moreover, we have established a correlation between the increase in leptin level with the increase of ESR $(r=0.92 ; p<0.05) ; p<0.05)$ index during destabilization of the disease course and development of the exacerbation phase of chronic obstructive pulmonary disease (III degree of severity) in 
Table 2. The level of leptin and ESR in studied patients with COPD of the III degree of bronchial obstruction depending on the body weight, $(\mathrm{M} \pm \mathrm{m})$.

\begin{tabular}{|c|c|c|c|c|c|c|}
\hline \multirow[b]{2}{*}{ Indices } & \multicolumn{2}{|c|}{ Main Group } & \multirow[b]{2}{*}{$\begin{array}{c}\text { Control } \\
\text { group, } \\
\text { n-12 }\end{array}$} & \multicolumn{2}{|c|}{ Comparison Group } & \multirow[b]{2}{*}{$\begin{array}{c}\text { Control } \\
\text { group, } \\
n=11\end{array}$} \\
\hline & $\begin{array}{c}1 \text { subgroup } \\
\text { Remission } \\
\text { phase, } \mathrm{n}=18\end{array}$ & $\begin{array}{l}2 \text { subgroup } \\
\text { Exacerbation } \\
\text { phase, } n=27\end{array}$ & & $\begin{array}{c}1 \text { subgroup } \\
\text { Remission } \\
\text { phase, } \mathrm{n}=25\end{array}$ & $\begin{array}{l}2 \text { subgroup } \\
\text { Exacerbation } \\
\text { phase, } n=42\end{array}$ & \\
\hline Leptin, $\mathrm{ng} / \mathrm{ml}$ & $29.5 \pm 4.1 * \circ$ & $53.1 \pm 4.7 \#^{\circ}$ & $12.0 \pm 2.4$ & $11.5 \pm 2.2 *$ & $16.1 \pm 2.7 \#$ & $7.2 \pm 1.3$ \\
\hline $\mathrm{ESR}, \mathrm{mm} / \mathrm{h}$ & $17.8 \pm 2.7 * \circ$ & $22.5 \pm 2.0 \#^{\circ}$ & $11.7 \pm 3.1$ & $12.9 \pm 3.0 *$ & $17.3 \pm 2.5 \#$ & $9.7 \pm 3.2$ \\
\hline
\end{tabular}

Notes:

* - statistically significant difference of the index compared to the control group $(\mathrm{p}<0.05)$;

\# - statistically significant difference of the index in the comparison between the phase of remission and the phase of exacerbation of the pathologic process $(\mathrm{p}<0.05)$;

$\circ$ - statistically significant difference compared with the corresponding index in the comparison groupof patients $(\mathrm{p}<0.05)$.

patients with excessive body weight.

Analyzing the obtained data it should be assumed that the pathogenetic role of leptin in the course and rapid progression of COPD GOLD III in patients with excessive body weight belongs to its proinflammatory effect.

\section{Conclusions}

1. Overweight is a factor in rapid progression of COPD GOLD III, that is evidenced by 1.2fold shorter duration of the disease $(\mathrm{p}<0.05)$ with parallel decrease at 2.1 pack-years of smoking history.

2. COPD (III degree of bronchial obstruction) in the remission phase in patients with excessive body weight is accompanied by more significant increase in the blood serum leptin level 2.6-fold $(\mathrm{p}<0.05)$ and ESR - 1.4-fold $(\mathrm{p}<0.05)$, as compared with the corresponding indices in patients with normal body weight.

3. The development of exacerbation phase of COPD GOLD III in patients with excessive body weight is accompanied by even more dramatic increase in the level of leptin at $69.7 \%$ as compared with the indices observed in patients with normal body weight, and moreover, these changes correlate with the increase of ESR level $(r=0.92 ; p<0.05)$.

\section{References}

[1] Bychkova SA, Bychkova NH. Clinical and functional peculiarities of the course of chronic obstructive pulmonary disease combined with metabolic syndrome. Vrachebnoe Delo. 2014;7-8:54-59. DOI: https: / / doi .org/ $10.31450 /$ ukrjnd.1 (45).2015.02

[2] Hashynova KYu. Influence of comorbid pathology on the frequency of hospitalizations with exacerbation on chronic obstructive pulmonary disease. Calician Medical Journal. 2014; 21(3):15-18.

[3] Humeniuk MI, Ilyinska IF, KharchenkoSevriukova HS. Systemic inflammatory markers in patients with COPD. Ukr.Pulmonol.Zhurnal. 2014;3:33-36.

[4] Dihtiar NI, Herasymenko ND, Savchenko LV, et al. Low-grade systemic inflammation as the common ground for chronic obstructive pulmonary disease and comorbid conditions. Ukr.Pulmonol.Zhurnal. 2016; 3: 64-68.64.

[5] Konopkina LI. Diagnostic significance of some markers of systemic inflammation in the infectious exacerbation of chronic obstructive pulmonary disease. Ukr. Pulmonol. Zhurnal. 2012; 3: 31-34. 
[6] Mostovyy YuM. Chronic obstructive pulmonary disease. Key issues. Ukr.Med.Chasopys. 2016; 4: 63-66.

[7] Order of the Ministry of Health of Ukraine \#555 dated June 27, 2013 "On approval and implementation of medicaltechnological documents on standardization of medical care in chronic obstructive pulmonary disease". Kyiv, 2013:146p. URL: http://www.moz.gov.ua/ua/ portal/dn_20131008_0868.html.

[8] Ostrovskyy MM, Mostovyy YuM, Pertseva TO. Obstructive pulmonary disease: the realities of clinical practice. Zdorovya Ukrayiny. 2017; 2 : 5-7.

[9] Ostrovskyy MM, Stovban MP. Phenotype of COPD with frequent exacerbations: the influence on the rate of progression of the disease and the prognosis for the patient. Zdorovya Ukrayiny. 2013; 3(23): 29-30.

[10] Pertseva TO, Sanina NA. The role of systemic inflammatory processes in the pathogenesis of chronic obstructive pulmonary disease. Ukr.Pulmonol.Zhurnal. 2012; 4: 48-50.

[11] Mostovoi YuM, Rasputina LV, Dovhan AO, Ovcharuk MV. The problem of comorbid conditions in the National agreement on the diagnosis and treatment of chronic obstructive pulmonary disease from the standpoint of own experience. Discussion of the Order \#555. Bukovynskyy Medychnyy Visnyk. 2014; 18(3): 221-226.

[12] Savchenko LV, Kaydashev IP. The role of some proinflammatory cytokines in the development of chronic obstructive pulmonary disease against the background of obesity. Problemy ekolohiyi ta medytsyny.2015; 19(3/4): 79.

[13] Savchenko LV, Kaidashev IP. Alimentary obesity as a result of eating behaviour violation impairs the clinical course of chronic obstructive pulmonary disease. Ukr. Pulmonol. Zhurnal. 2017; 2: 33-36.

[14] Tolokh OS. Chronic obstructive pulmonary disease: new solutions to old problems. Klinichna imunolohiia. Alerholohiia. Infektolohiia. 2017; 1(98): 16-22.

[15] Treumova SI, Petrov YeYe, Boriak VP. Chronic obstructive pulmonary disease combined with metabolic syndrome. Visnyk problem biolohii i medytsyny. 2015; 1: 33-36.

[16] Feshchenko YuI. COPD in Ukraine: problems and ways of solution. Zdoroviyia Ukrayiny. March 27, 2015. http://health-ua. com/article/3876.html

[17] Feshchenko YuI, Chaikovskyy YuB, Ostrovskyy MM, et al. Chronic obstructive pulmonary disease. New shades of the problem. Ivano-Frankivsk. 2016; 400.

[18] Agusti A, Soriano JB. COPD as a systemic disease. COPD. 2008;5:133-138. DOI: https://doi.org/10.1080/ 15412550801941349 [PMid:18415812]

[19] Rabe KF, Lichtinghagen R, et al. Angiopoietinlike protein 4 and cardiovascular function in COPD. BMJ Open Respiratory Research. 2016; 3, 1. DOI: https://doi.org/ $10.1136 /$ bmjresp-2016-000161 [PMid:27933182 PMCid:PMC5133419]

[20] Kumor-Kisielewska A, KierszniewskaStepien D, Pietras T, et al. Assessment of leptin and resistin in patients with chronic obstructive pulmonary disease. Polskie Archiwum Medycyny Wewnetrznei. 2013; 123(5):215-220. DOI: https: //doi.org/10.20452/pamw.1724

[21] Bhatt S. Adiponectin receptor: a potential target for diabetes, obesity and other disorders. Pharmacologyonline. 2010;1: 117-130.

[22] Bing C, Mracek T, et al. Zinc-a2-glycoprotein: an adipokine modulator of body fat 
mass? International J. of Obesity. 2010; 34: 1559-1565. DOI: https: //doi.org/10.1038/ijo.2010.105

[PMid:20514048]

[23] Breyer M-K, Rutten EPA, Vernooy JHJ, et al. Gender differences in the adipose secretome system in chronic obstructive pulmonary disease (COPD): A pivotal role of leptine. Respiratory Medicine. 2011; 105: 1046-1053. DOI: https://doi.org/10.1016/j. rmed.2011.02.001 [PMid:21367591]

[24] Battaglia S, Spatafora M, Paglino G, et al. Ageing and COPD affect different domains of nutritional status: the ECCE study. Eur. Respir. J. 2011; 37: 1340-1345. DOI: https://doi.org/10.1183/ 09031936.00032310 [PMid:21071469]

[25] Global Initiative for Chronic Obstructive Lung Diseases (GOLD). Global strategy for diagnosis, management, and prevention of chronic obstructive pulmonary disease. NHLBI/WHO workshop report. Updated 2018. URL: http: //www.goldcopd.com

[26] Han MK, Agusti A, Calverley PM, et al. COPD phentypes: The future of COPD. Am. J. Respir. Crit. Care Med. 2010; 182: 598604. DOI: https: / / doi .org/10.1164/ rccm.200912-1843CC [PMid:20522794 PMCid:PMC6850732]

Received: 2019-09-11

Revised: 2019-11-04

Accepted: 2019-12-09 